\title{
THE ANEMIA OF LIVER DISEASE: OBSERVATIONS ON ITS MECHANISM 1
}

\author{
By JAMES H. JANDL 2 \\ (From the Thorndike Memorial Laboratory, Second and Fourth Medical Services [Harvard], \\ Boston City Hospital, and the Department of Medicine, Harvard Medical School, \\ Boston, Mass.)
}

(Submitted for publication September 20, 1954; accepted November 3, 1954)

The frequent association of anemia with chronic liver disease provides a possible means of examining the role of the liver with respect to the formation and destruction of red blood cells. An understanding of the mechanism of this anemia has been retarded by the frequent appearance in afflicted patients of complicating factors such as blood loss, infection, neoplasm, and occasionally nutritional macrocytic anemia, as well as by the diversity of the actual hepatic lesions. Furthermore, the proliferative aspects of the liver and spleen in hepatic cirrhosis render it theoretically likely that in this common form of chronic liver disease superimposed pathologic, as well as altered physiologic, processes act upon the production, sustenance, and destruction of red cells. Nevertheless, knowledge of the pattern of red cell turnover in chronic liver disease is of basic clinical and physiologic interest.

A number of surmises have been offered to account for the pathogenesis of the anemia of liver disease. The hypothesis that this anemia is metabolically similar to pernicious anemia and that it arises from defective storage of the subsequently identified Vitamin $B_{12}(1-3)$ has been generally rejected for several reasons, namely: The morphologic dissimilarities of the two types of anemia $(4,5)$; the failure of typical cases to respond to preparations containing Vitamin $B_{12}$ (6) ; the demonstration of anti-pernicious anemia activity in the liver of cirrhotic patients with macrocytic anemia (7); and the inability of liver extract to prevent anemia during experimental liver injury (8). More recently it has been suggested that another, unrelated metabolic defect exists (6), possibly exaggerated in some cases

1 This investigation was supported in part by research grant G-3507 $\left(C_{2}\right)$ from the National Institutes of Health, Public Health Service.

'Public Health Service Research Fellow of the National Institute of Arthritis and Metabolic Diseases. by hemodilution (9). On the other hand, the elevation of the reticulocyte levels $(10,11)$ and the extension of the marrow organ $(12,13)$, reported to occur in chronic liver disease, are more suggestive of increased red cell destruction than of metabolic defects inhibiting production. Certain patients have been described as having increased rates of urobilinogen excretion during chronic liver disease $(14,15)$ although no clear correlation existed between the amount of urobilinogen excreted and the presence or the degree of anemia. Occasional instances of classical acquired hemolytic anemia with a positive direct antiglobulin (Coombs) test have been reported in association with chronic liver disease (16), but such cases are exceptional. An increase in diameter and decrease in thickness without increase in volume manifest also as an increase in resistance to osmotic lysis of the red cells of certain jaundiced patients have been reported to be an acquired characteristic (17). This red cell alteration, however, has been described in association with biliary obstruction (18) and infectious hepatitis (19) rather than with chronic liver disease, and thus an essential relationship to the anemia of liver disease has not been demonstrated.

This is a report of a series of 20 patients with chronic liver disease and anemia who have been studied by a number of hematologic techniques. A later report will be concerned primarily with nutritional studies on the same group of patients, with particular attention to the metabolism of folic acid.

\section{CLINICAL MATERIAL}

Twenty patients with chronic liver disease and various degrees of anemia, in whom no evidence existed of current or previous blood loss, were transferred to a special metabolic ward for study under controlled conditions. The group consisted of 10 males and 10 females whose ages ranged from 28 to 64 years. All were well-documented chronic alcoholics in whom a diagnosis of cir- 
rhosis was made on clinical grounds. This diagnosis was verified pathologically in six patients in whom confirmatory liver biopsies were considered necessary, and in three patients at autopsy. Observations were begun on the average six days after hospital admission, within five days in 12 patients, and were continued for an average of 36 days. Of the 20 patients, 11 improved clinically while under observation, 4 showed no improvement, and 5 died in hepatic coma.

\section{METHODS}

Red blood cell counts, hemoglobin determinations, and hematocrit readings were performed every three or four days by standard techniques (20). Reticulocytes were enumerated daily using the dry method (20) and counting 1,000 cells. Bone marrow specimens were aspirated from the iliac crest and at least 200 nucleated cells were counted differentially. The osmotic fragility of the red cells was measured before and after sterile incubation of defibrinated blood at $37^{\circ}$ C. for 24 hours (21), with correction for the osmotic effect of $0.1 \mathrm{ml}$. of whole blood added to each $1 \mathrm{ml}$. sample of hypotonic salt solution (22). The mechanical fragility of the red cells before and after incubation was determined on blood samples corrected to a hematocrit of 35 per cent (23). Auto-agglutinins and auto-hemolysins were searched for at least once in each patient over a pH range of 6 to 8 (24) and after incubation of the blood at $4^{\circ}, 25^{\circ}$, and $37^{\circ}$ C. A direct antiglobulin (Coombs) test (25) employing serial dilutions of the antiglobulin serum was performed at least twice on each patient. Trypsinized red cell preparations were employed in a modification of the method of Rosenthal, Dameshek, and Burkhardt (26), in order to demonstrate incomplete antibodies in the patients' sera.

Whole blood glutathione levels were measured iodometrically (27) and the content of alkali-resistant hemoglobin was estimated by the method of Singer, Chernoff, and Singer (28). Spectrophotometric curves were determined on hemoglobin solutions of six patients over a wave length range of 400 to $700 \mathrm{~m} \mu$.; the test solutions contained $250 \mathrm{mg}$. of oxyhemoglobin per $100 \mathrm{ml}$. of 0.1 per cent sodium carbonate in water.

Serum iron levels were measured by the method of Kitzes, Elvehjem, and Schuette (29) employing 1,10(ortho)-phenanthroline; the serum iron-binding capacity was determined by a modification of the method described by Rath and Finch (30). Gross estimations of bone marrow and liver hemosiderin were made on the basis of the prussian blue reaction (20). The liver tissues were counterstained with basic fuchsin.

The methods of Schwartz, Sborov, and Watson (31) were employed for quantitative measurements of stool and urine urobilinogen content during four-day collection periods. One to five such collections were carried out on each patient. Frequent determinations were made on the serum albumin and globulin levels $(32,33)$, the serum bilirubin, the serum retention of bromsulphalein, the formol gel reaction, and the serum stability in terms of cephalin flocculation, thymol turbidity, and thymol flocculation (20).

The survival of normal red cells in these patients was determined by the Ashby differential agglutination method (34) as modified for the use of dried rabbit antihuman blood group serum. ${ }^{3}$ Anti-M serum was used in most instances; in a few, Anti- $A$ and Anti-B sera were used. The base-line inagglutinable red cell counts of the recipients averaged 12,000 (range: 2,000 to 32,000 ) red cells per cubic millimeter. The packed red cells from one or occasionally two pints of normal donor blood preserved in ACD solution were given within 48 hours of procurement. All donor cell-recipient plasma combinations were examined for agglutination at $37^{\circ} \mathrm{C}$. and a Coombs test was then performed on the donor cells. The initial post-transfusion inagglutinable red cell count was made 24 to 48 hours after transfusion; thereafter inagglutinable red cell counts were made every few days or weeks, depending upon their rate of fall, until baseline levels were again reached. Although paired total red cell counts were performed with the inagglutinable red cell counts, results were recorded as actual inagglutinable counts rather than as percentage values in order to minimize the dilution effect of an increasing red cell mass. The inagglutinable red cell count at "zero-time" was obtained by extrapolation of the best visually adopted line, and in graphic representation all points were expressed as percentages of this value. Since the survival curves were not generally rectilinear, and in order to avoid debatable methods for distinguishing extrinsic and intrinsic destructive processes, red cell survival was expressed as half-survival, i.e., the period of time in which half the transfused cells had disappeared.

The survival of autogenous red cells was determined in two subjects by labeling with radioactive chromium $\left(\mathrm{Cr}^{\mathrm{a}}\right)$, as described by Gray and Sterling (35) and as modified for red cell survival studies (36). In this method $50 \mathrm{ml}$. of the subject's blood was suspended in ACD solution and incubated with 60 to $100 \mu \mathrm{c}$. of $\mathrm{Na}_{2} \mathrm{Cr}^{\mathrm{NO}}$, at room temperature for one hour. The hexavalent $\mathrm{Cr}^{\mathrm{m}}$ remaining in the plasma was then reduced with $125 \mathrm{mg}$. of ascorbic acid (37) prior to reinjection of the tagged cells with a calibrated syringe. Radioactivity in the samples was determined with a welltype scintillation counter.

Venous blood buffy coat Vitamin C levels (38), serum Vitamin $B_{12}$ levels (39), and urine folic acid (40) and citrovorum factor levels (41) were measured by methods modified as described elsewhere (42). Full details of these measurements will be published separately.

\section{RESULTS}

\section{Morphology}

The morphologic data, which include normal values for this laboratory, are recorded in Table I.

\footnotetext{
${ }^{8}$ Kindly provided by Lederle Laboratories Division, American Cyanamid Company.
} 
TABLE I

Observations relating to the peripheral blood, bone marrow, and liver function in 20 cases of cirrhosis and anemia

\begin{tabular}{|c|c|c|c|c|c|c|c|c|c|c|c|c|c|}
\hline \multirow[b]{3}{*}{ Patient } & \multirow[b]{3}{*}{ Age } & \multirow[b]{3}{*}{ Sex } & \multicolumn{6}{|c|}{ Peripheral blood } & \multicolumn{5}{|c|}{ Bone marrow differential count } \\
\hline & & & \multirow[b]{2}{*}{$\begin{array}{c}\mathrm{RBC} \\
\times 10 \% / \mathrm{mm} . \\
\end{array}$} & \multirow[b]{2}{*}{$\begin{array}{l}\text { Hemo- } \\
\text { globin } \\
\text { sm. \% }\end{array}$} & \multirow[b]{2}{*}{$\begin{array}{c}\text { Hema- } \\
\text { tocrit } \\
\text { ool. } \%\end{array}$} & \multirow[b]{2}{*}{$\underset{m^{3}}{\text { MCV }}$} & \multirow[b]{2}{*}{$\begin{array}{c}\text { МCHC } \\
\text { sm.\% }\end{array}$} & \multirow[b]{2}{*}{$\begin{array}{c}\text { MCH } \\
\text { mus. }\end{array}$} & \multicolumn{2}{|c|}{ Granulocytes } & \multirow{2}{*}{$\begin{array}{c}\text { Meta- } \\
\text { myelo- } \\
\text { cytes } \\
\%\end{array}$} & \multirow[b]{2}{*}{$\begin{array}{c}\text { Myelo- } \\
\text { cytes } \\
\%\end{array}$} & \multirow[b]{2}{*}{$\begin{array}{c}\text { Myelo } \\
\text { blasts } \\
\%\end{array}$} \\
\hline & & & & & & & & & $\begin{array}{r}\text { Mature } \\
\%\end{array}$ & Young & & & \\
\hline Normal* & & $\begin{array}{l}\mathbf{M} \\
\mathbf{F}\end{array}$ & $\begin{array}{l}5.0 \pm 0.3 \\
4.4 \pm 0.3\end{array}$ & $\begin{array}{l}14.8 \pm 0.8 \\
13.0 \pm 0.8\end{array}$ & $\begin{array}{l}45.9 \pm 2.7 \\
42.1 \pm 2.0\end{array}$ & $\begin{array}{l}91 \pm 7 \\
95 \pm 6\end{array}$ & $\begin{array}{l}32 \pm 2 \\
31 \pm 5\end{array}$ & $\begin{array}{l}30 \pm 2 \\
29 \pm 2\end{array}$ & $17 \pm 5$ & $26 \pm 8$ & $10 \pm 4$ & $12 \pm 5$ & $1 \pm 1$ \\
\hline J. B. & 42 & $\mathbf{M}$ & 3.44 & 9.6 & 32.3 & 94 & 30 & 28 & 12 & 18 & 8 & 16 & $\mathbf{0}$ \\
\hline J.L. & 47 & $\mathbf{M}$ & 3.03 & 10.5 & 34.1 & 112 & 31 & 35 & 8 & 25 & 14 & 12 & 1 \\
\hline E. L. & 54 & $\mathbf{F}$ & 2.22 & 6.9 & 25.3 & 114 & 27 & 31 & 5 & 38 & 13 & 15 & $i$ \\
\hline B. L. & 63 & $\mathbf{F}$ & 3.19 & 9.9 & 32.5 & 102 & 30 & 31 & 8 & 23 & 7 & 15 & o \\
\hline М. H. & 41 & $\mathbf{M}$ & 4.08 & 12.1 & 40.1 & 98 & 30 & 30 & 16 & 16 & 14 & 9 & 1 \\
\hline J. R. & 49 & $\mathbf{M}$ & 4.60 & 13.6 & 42.0 & 91 & 32 & 30 & 32 & 18 & 6 & 3 & 0 \\
\hline H. S. & 56 & $\mathbf{M}$ & 3.02 & 8.3 & 28.9 & 96 & 29 & 27 & 17 & 20 & 7 & 12 & 1 \\
\hline J. G. & 55 & $\mathbf{M}$ & 3.74 & 10.5 & 35.0 & 94 & 30 & 28 & 6 & 32 & 4 & 12 & 2 \\
\hline D. L. & 28 & $\mathbf{M}$ & 1.35 & 5.1 & 15.0 & 111 & 34 & 38 & 18 & 18 & 2 & 9 & 0 \\
\hline M. Sc. & 56 & $\mathbf{F}$ & 2.89 & 9.3 & 30.7 & 106 & 30 & 32 & 2 & 34 & 9 & 26 & O \\
\hline M. C. & 50 & $\mathbf{F}$ & 2.74 & 9.0 & 30.0 & 109 & 30 & 33 & 16 & 24 & 3 & 8 & 0 \\
\hline F. T. & 31 & $\mathbf{F}$ & 2.95 & 9.8 & 34.0 & 115 & 29 & 33 & 9 & 20 & 7 & 6 & 0 \\
\hline M. L. & 64 & $\mathbf{M}$ & 2.30 & 7.9 & 24.8 & 108 & 32 & 32 & 4 & 21 & 9 & 7 & 0 \\
\hline A. J. & 39 & $\mathbf{F}$ & 1.95 & 6.7 & 23.8 & 122 & 28 & 34 & 10 & 11 & 3 & 5 & 2 \\
\hline L. S. & 37 & $\mathbf{F}$ & 2.36 & 5.8 & 24.8 & 105 & 23 & 25 & 20 & 17 & 7 & 11 & 0 \\
\hline M. D. & 50 & $\mathbf{F}$ & 1.98 & 7.2 & 23.9 & 121 & 30 & 36 & 23 & 15 & 6 & 8 & 1 \\
\hline H. B.† & 41 & $\mathbf{M}$ & 1.42 & 5.4 & 16.3 & 115 & 33 & 38 & $3 \ddagger$ & $25 \ddagger$ & 9t & $15 \ddagger$ & 0 \\
\hline J. Ba.t & 49 & $\mathbf{M}$ & 0.71 & 2.9 & 9.2 & 130 & 32 & 41 & $7 \ddagger$ & $25 \ddagger$ & $7 \ddagger$ & $16 !$ & $2 \ddagger$ \\
\hline A. $\mathrm{K} . \dagger$ & 50 & $\mathbf{F}$ & 0.96 & 4.6 & 15.0 & 156 & 31 & 48 & 10 & $21 t$ & 9t & $21 t$ & 0 \\
\hline M.S.† & 61 & $\mathbf{F}$ & 1.34 & 5.7 & 19.1 & 143 & 30 & 43 & $23 \ddagger$ & $17 t$ & $7 \ddagger$ & $10 t$ & 1 \\
\hline
\end{tabular}

* Normal hematologic values for this laboratory are expressed as the mean \pm 1 standard deviation.

t Co-existing folic acid deficiency.

f Abnormal (see text).

TABLE I-Continued

Observations relating to the peripheral blood, bone marrow, and liver function in 20 cases of cirrhosis and anemia

\begin{tabular}{|c|c|c|c|c|c|c|c|c|c|c|c|c|c|c|}
\hline \multirow[b]{3}{*}{$\begin{array}{c}\text { Lympho- } \\
\text { cytes } \\
\% \\
\end{array}$} & \multirow[b]{3}{*}{$\begin{array}{c}\text { Plasma } \\
\text { cells } \\
\%\end{array}$} & \multirow[b]{3}{*}{$\begin{array}{c}\text { Mono- } \\
\text { cytes } \\
\%\end{array}$} & \multicolumn{9}{|c|}{ Bone marrow differential count (continued) } & \multirow[b]{3}{*}{ Sex } & \multirow[b]{3}{*}{ Age } & \multirow[b]{3}{*}{ Patient } \\
\hline & & & & \multicolumn{2}{|c|}{ Normoblasts } & \multicolumn{2}{|c|}{$\begin{array}{c}\text { Late } \\
\text { erythroblasts }\end{array}$} & \multicolumn{2}{|c|}{$\begin{array}{c}\text { Early } \\
\text { erythroblasts }\end{array}$} & \multicolumn{2}{|c|}{$\begin{array}{c}\text { Pro- } \\
\text { erythroblasts }\end{array}$} & & & \\
\hline & & & $\begin{array}{c}\text { Histio- } \\
\text { cyttes } \\
\%\end{array}$ & $\begin{array}{r}\text { Normal } \\
\%\end{array}$ & $\underset{\text { normal }}{\text { Ab- }}$ & $\begin{array}{r}\text { Normal } \\
\%\end{array}$ & $\underset{\text { normal }}{\text { Ab- }}$ & $\begin{array}{r}\text { Normal } \\
\%\end{array}$ & $\underbrace{\text { Ab- }}_{0}$ & $\begin{array}{r}\text { Normal } \\
\%\end{array}$ & $\underset{\text { normal }}{\text { Ab- }}$ & & & \\
\hline $15 \pm 6$ & $1 \pm 1$ & $3 \pm 1$ & $1 \pm 1$ & $11 \pm 5$ & $\mathbf{0}$ & $4 \pm 2$ & $\mathbf{0}$ & $1 \pm 1$ & $\mathbf{0}$ & $0.2 \pm 0.2$ & $\mathbf{0}$ & $\mathbf{M}$ & & *Normal \\
\hline 10 & 3 & o & 0 & 16 & 0 & 12 & 0 & 4 & 0 & 1 & O & $\mathbf{M}$ & 42 & J. B. \\
\hline 4 & O & 5 & 1 & 11 & o & 16 & o & 2 & o & 1 & O & $\mathbf{M}$ & 47 & J. L. \\
\hline 8 & 2 & 1 & o & 8 & o & 7 & o & 2 & 0 & O & o & $\mathbf{F}$ & 54 & E. L. \\
\hline 9 & 0 & 2 & 1 & 11 & 0 & 17 & 1 & 4 & 1 & 1 & o & F & 63 & B. L. \\
\hline 8 & 4 & o & 1 & 16 & 0 & 10 & o & 3 & o & 2 & 0 & $\mathbf{M}$ & 41 & M. H. \\
\hline 17 & 0 & 1 & 0 & 11 & o & 10 & o & 2 & o & 0 & o & $\mathbf{M}$ & 49 & J. R. \\
\hline 10 & 1 & 1 & 1 & 22 & 0 & 5 & o & 1 & 0 & 2 & 0 & $\mathbf{M}$ & 56 & H. S. \\
\hline 8 & o & 2 & 0 & 16 & o & 12 & o & 3 & 0 & 3 & o & $\mathbf{M}$ & 55 & J. G. \\
\hline 5 & 0 & 1 & 3 & 4 & 2 & 5 & 5 & 15 & 5 & 6 & 2 & $\mathbf{M}$ & 28 & D. L. \\
\hline 7 & o & 1 & 0 & 4 & 2 & 4 & 3 & 3 & i & 2 & 2 & F & 56 & M. Sc. \\
\hline 12 & $\mathbf{0}$ & 7 & - & 19 & $\mathbf{0}$ & 9 & $\mathbf{0}$ & 1 & $\mathbf{0}$ & 1 & $\mathbf{0}$ & F & 50 & M. C. \\
\hline 16 & 2 & 1 & 1 & 14 & 1 & 13 & 2 & 4 & 1 & 3 & o & $\mathbf{F}$ & 31 & F. T. \\
\hline 4 & 3 & 0 & 0 & 27 & 1 & 18 & 2 & 2 & 0 & 1 & 1 & $\mathbf{M}$ & 64 & M. L. \\
\hline 12 & 1 & 1 & 1 & 13 & o & 24 & o & 13 & 0 & 4 & o & F & 39 & A. J. \\
\hline 6 & 1 & 7 & 6 & 12 & o & 11 & o & 1 & 0 & 1 & o & $\mathbf{F}$ & 37 & L. S. \\
\hline 8 & 1 & 1 & o & 22 & 1 & 10 & $\mathbf{1}$ & 2 & o & 1 & o & $\mathbf{F}$ & 50 & M. D. \\
\hline $11 \ddagger$ & 0 & o & 2 & 0 & 2 & 1 & 1 & 3 & 10 & 1 & 17 & $\mathbf{M}$ & 41 & H. B.† \\
\hline 3 & o & o & o & o & 4 & 2 & 11 & O & 8 & o & 15 & $\mathbf{M}$ & 49 & J. Ba.t \\
\hline 16 & o & o & o & 6 & 2 & 4 & 1 & 3 & 3 & 3 & 1 & F & 50 & A. $\mathbf{K} . \dagger$ \\
\hline 12 & $\mathbf{0}$ & 2 & $\mathbf{0}$ & 5 & 4 & 3 & 5 & 2 & 5 & 2 & 2 & F & 61 & M. S.t \\
\hline
\end{tabular}


TABLE I-Continued

Obserrations relating to the peripheral blood, bone marrow, and liver function in 20 cases of cirrhosis and anemia

\begin{tabular}{|c|c|c|c|c|c|c|c|c|c|c|c|c|c|c|c|}
\hline \multirow{4}{*}{$\frac{\text { Patient }}{\text { Normal* }}$} & \multirow[b]{3}{*}{ Age } & \multirow[b]{3}{*}{ Sex } & & & & \multicolumn{10}{|c|}{ Liver function tests } \\
\hline & & & Liver & Spleen & Ascites & \multirow{3}{*}{$\begin{array}{c}\begin{array}{c}\text { Icterus } \\
\text { index } \\
\text { on ad- } \\
\text { mission }\end{array} \\
6 \pm 2\end{array}$} & \multicolumn{2}{|c|}{ Bilirubin } & \multirow{3}{*}{$\begin{array}{c}\begin{array}{c}\text { BSP } \\
\text { reten- } \\
\text { tion } \\
\%\end{array} \\
0-5\end{array}$} & \multirow{3}{*}{$\begin{array}{c}\begin{array}{c}\text { Ceph- } \\
\text { alin } \\
\text { foccu- } \\
\text { lation }\end{array} \\
0-1+\end{array}$} & \multirow{3}{*}{$\begin{array}{c}\begin{array}{c}\text { Thy- } \\
\text { mol } \\
\text { tur- } \\
\text { bidity }\end{array} \\
0-2.1\end{array}$} & \multirow{3}{*}{$\begin{array}{c}\text { Thy- } \\
\text { mol } \\
\text { foccu- } \\
\text { lation }\end{array}$} & \multirow{3}{*}{$\frac{\begin{array}{c}\text { Albu- } \\
\text { min }\end{array}}{4.1 \pm 0.4}$} & \multirow{3}{*}{$\frac{\begin{array}{c}\text { Glob- } \\
\text { ulin } \\
\text { gm. \% }\end{array}}{2-3}$} & \multirow{3}{*}{$\frac{\begin{array}{c}\text { Formol } \\
\text { gel }\end{array}}{0}$} \\
\hline & & & \multicolumn{3}{|c|}{$\begin{array}{c}\text { Distance below } \\
\text { costal margin } \\
\mathrm{cm} .\end{array}$} & & $\begin{array}{c}\text { Prompt } \\
\text { direct } \\
\text { ms. }\end{array}$ & $\%^{\text {Total }}$ & & & & & & & \\
\hline & & $\begin{array}{l}\mathbf{M} \\
\mathbf{F}\end{array}$ & 0 & 0 & 0 & & $0.1 \pm 0.1$ & $0.7 \pm 0.3$ & & & & & & & \\
\hline J. B. & 42 & $\mathbf{M}$ & 5 & 2 & $3+$ & 65 & 0.7 & 2.7 & 42 & $4+$ & 4.6 & $2+$ & 2.3 & 3.4 & $1+$ \\
\hline J. L. & 47 & $\mathbf{M}$ & 19 & 0 & $1+$ & 14 & 0.5 & .6 & 45 & $3+$ & 1.7 & 0 & 3.4 & 2.2 & 0 \\
\hline E. L. & 54 & $\mathbf{F}$ & 2 & $\mathbf{0}$ & $4+$ & 10 & 0.2 & .6 & 22 & $4+$ & 2.3 & 0 & 3.1 & 2.4 & 0 \\
\hline B. L. & 63 & $\mathbf{F}$ & $?$ & $?$ & $4+$ & 5 & 0.2 & .7 & 45 & 0 & 1.1 & 0 & 2.2 & 2.8 & 0 \\
\hline М. H. & 41 & $\mathbf{M}$ & 10 & 4 & $3+$ & 20 & 0.4 & 2.2 & 60 & $4+$ & 4.1 & $2+$ & 2.18 & 4.47 & $4+$ \\
\hline J. R. & 49 & $\mathbf{M}$ & $?$ & $?$ & $4+$ & 20 & 0.6 & 1.8 & 35 & $3+$ & 3.1 & 0 & 2.28 & 3.12 & 0 \\
\hline H. S. & 56 & $\mathbf{M}$ & 18 & 0 & 0 & 15 & 0.1 & .6 & 40 & 0 & 0.8 & 0 & 2.96 & 3.04 & 0 \\
\hline J. G. & 55 & $\mathbf{M}$ & 7 & 0 & $\mathbf{0}$ & 75 & 0.8 & 1.5 & 45 & $2+$ & 0.8 & O & 2.35 & 4.26 & $2+$ \\
\hline D. L. & 28 & $\mathbf{M}$ & 14 & 7 & 0 & 50 & 1.4 & 2.7 & 26 & $4+$ & 1.3 & $1+$ & 3.0 & 3.6 & $1+$ \\
\hline M. Sc. & 56 & $\mathbf{F}$ & 10 & 0 & $2+$ & 4 & 0.3 & .8 & 30 & 0 & 1.2 & 0 & 3.22 & 2.68 & 0 \\
\hline M. C. & 50 & $\mathbf{F}$ & 3 & 0 & 0 & 10 & 0.2 & .6 & 21 & 0 & - & - & 3.15 & 3.20 & $1+$ \\
\hline F. T. & 31 & $\mathbf{F}$ & 17 & 3 & 0 & 50 & 1.2 & 3.1 & 42 & $1+$ & - & - & 2.68 & 2.40 & 0 \\
\hline M.L. & 64 & $\mathbf{M}$ & $?$ & $?$ & $4+$ & 35 & 1.9 & 6.2 & 57 & $4+$ & 6.7 & $3+$ & 1.62 & 4.30 & $4+$ \\
\hline A. J. & 39 & $\mathbf{F}$ & 10 & 2 & 0 & 4 & 0.1 & 1.0 & 9 & $3+$ & 0.9 & 0 & 4.03 & 1.03 & 0 \\
\hline L. S. & 37 & $\mathbf{F}$ & 12 & 4 & $4+$ & 104 & 12.0 & 24.4 & 68 & $3+$ & 3.4 & o & 2.8 & 1.9 & 0 \\
\hline M. D. & 50 & $\mathbf{F}$ & $?$ & $?$ & $4+$ & 75 & 4.3 & 12.6 & 68 & $4+$ & 4.1 & $2+$ & 1.8 & 4.2 & $4+$ \\
\hline H. B.t & 41 & $\mathbf{M}$ & 14 & 6 & 0 & 10 & 0.2 & .8 & 26 & 0 & 1.3 & 0 & 3.46 & 1.58 & 0 \\
\hline J. Ba.t & 49 & $\mathbf{M}$ & 5 & 0 & 0 & 10 & 0.6 & 1.9 & 40 & $4+$ & 5.3 & $\mathbf{0}$ & 2.37 & 2.29 & $\mathbf{0}$ \\
\hline A. K.† & 50 & $\mathbf{F}$ & 7 & 0 & 0 & 15 & 0.1 & 3 & 36 & $\mathbf{0}$ & 1.3 & 0 & 3.28 & 2.64 & 0 \\
\hline M. S.† & 61 & $\mathbf{F}$ & 6 & 0 & 0 & 5 & 0.4 & 1.5 & 36 & $3+$ & 2.0 & $1+$ & 2.97 & 2.27 & $\mathbf{0}$ \\
\hline
\end{tabular}

* Normal hematologic values for this laboratory are expressed as the mean \pm 1 standard deviation. t Co-existing folic acid deficiency.

$\ddagger$ Abnormal (see text).

It is evident that four patients (H. B., J. Ba., A. K., and M. S.) differed from the group as a whole in that the anemia was more severe and the increase of the mean corpuscular volume and mean corpuscular hemoglobin was generally greater. The marrow patterns of these four patients also differed from the others in exhibiting a large percentage of abnormal red cell precursors (i.e., megaloblasts), but the most striking and consistent departure from normal was in the appearance of the granulocyte series. These cells were large, with peculiarities of nuclear shape, chromatin, and mitoses of the kind found in pernicious anemia. Unlike the remainder of the patients in the group, these four patients subsequently responded hematopoietically to folic acid preparations. They can justifiably be considered as a morphologically separate group of cases with demonstrable folic acid deficiency complicating hepatic cirrhosis.

The remaining 16 patients had hemoglobin levels ranging from the lower limit of normal down to $5 \mathrm{gm}$. per cent, with an average value on admission of $8.8 \mathrm{gm}$. per cent. Macrocytosis, generally moderate or mild in degree, was present in all distinctly anemic cases. There was a rough correlation between the degree of anemia and the mean corpuscular volume although no correlation was apparent between either of these and the severity of liver damage as estimated with conventional liver function tests and with liver biopsy. The mean corpuscular hemoglobin concentration was, with one exception (L. S.), within the normal range. Abnormalities in the appearance of red cells were seldom marked; in 7 of the 16 patients, however, there was stippling, unrelated to the severity of anemia, and in most of the patients, prominently so in M. L. and L. S., occasional target cells were present. Nucleated red cells were present in small numbers in the peripheral blood of three of these patients, and in one of those subsequently responding to folic acid ( $H$. B.).

In all 16 patients not deficient in folic acid, there was an elevation of the reticulocyte levels, relative and absolute. This increased reticulocyte activity persisted in most patients for at least several weeks after admission, and generally abated only with improvement of hemoglobin values. The maximum reticulocyte level of these 16 


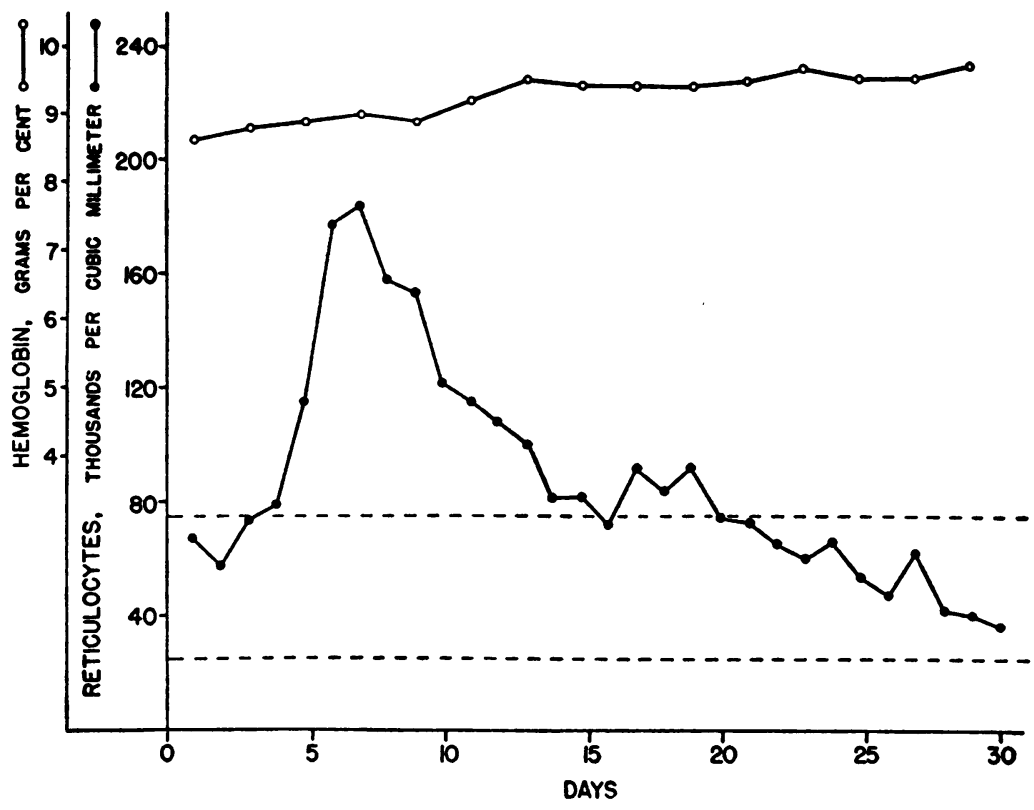

Fig. 1. The Spontaneous Increase in Reticulocyte Levels in Patients with Cirrhosis, Chronic Alcoholisy, and Anemia Following Hospitalization and Abstinence

Each point represents the mean of the values in five patients. For comparison absolute, rather than percentage, reticulocyte values were averaged. The upper and lower limits of normal are indicated by the horizontal interrupted lines.

TABLE II

Osmotic"and mechanical fragility determinations in 20 patients with cirrhosis and anemia

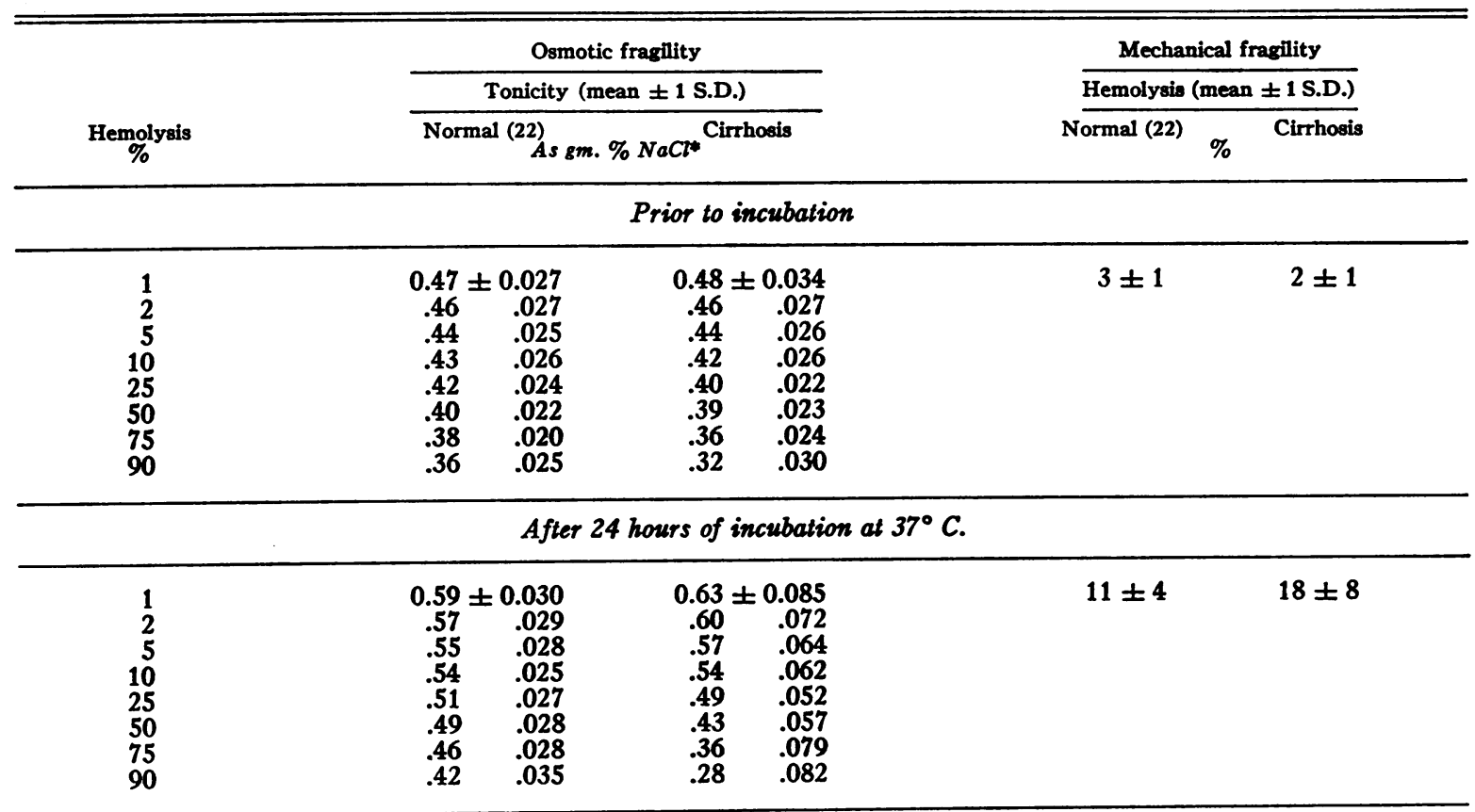

* Corrected for the tonicity change induced by the addition of blood to the saline solutions. 
patients averaged 8.6 per cent, with a range of from 2.3 to 24.6 per cent. In several patients, reticulocyte levels of from 10 to 20 per cent persisted for several weeks, and in one patient (A. J.), this high level continued despite an increase in the hemoglobin level to $11 \mathrm{gm}$. per cent. In all the patients who had continued to drink alcoholic beverages until admission and who were seen within one or two days after admission, there was a rise in reticulocyte level beginning a few days after admission and reaching a maximum, on an average, on the seventh day (Figure 1). This rise was especially marked in patient D. L. who, like the others, subsequently showed no response to folic acid in the presence of a persistent moderately severe anemia. Patient B. L. was maintained on 20 per cent glucose in water during the period of this reticulocytosis; the other patients were given a special diet low in animal protein and vegetables and almost free of Vitamin $B_{12}$. Three patients, M. L., A. J., and L. S., who had stopped drinking alcoholic beverages one or two weeks prior to entry showed reticulocyte levels of 8 to 14 per cent on admission.

\section{Red cell fragility}

The results of determinations of the osmotic and mechanical fragilities of the patients' red cells and, for comparison, the normal values for this laboratory (22) are presented in Table II. The summation curves of osmotic fragility and the mechanical fragility values of unincubated blood were essentially normal, although a small portion of the red cells of many of these patients were abnormally "resistant" to osmotic lysis. After incubation of the blood, hemolysis often began in less hypotonic solutions than when normal red cells are so treated; and in the majority of the patients the red cells most resistant osmotically increased their resistance, a finding observed in several kinds of anemia. Consequently, the slopes of the osmotic fragility curves characteristically were diminished by incubation and

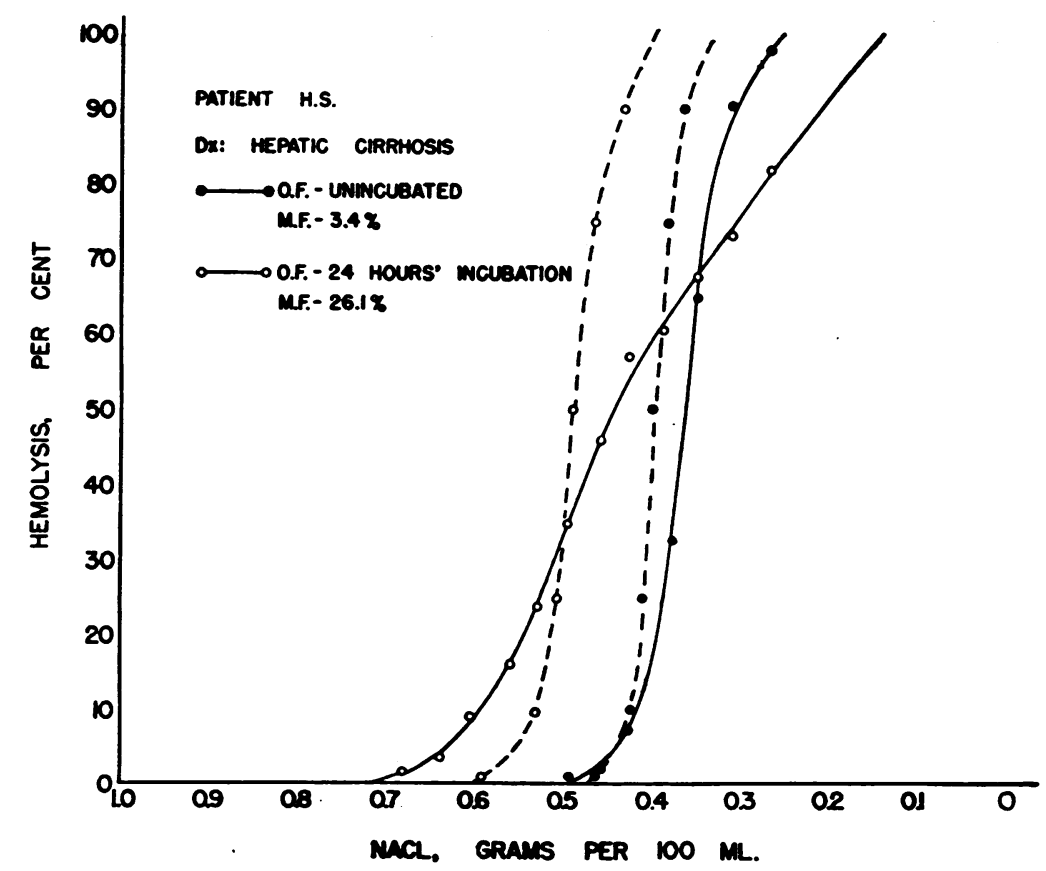

Fig. 2. The Osmotic Fragitity Curtes of the Red Cells of a Pattent with Cirrhosis and Anemia Before and After Incubation of the Blood AT $37^{\circ}$ C. FOR 24 Hours

The solid lines represent the osmotic fragility of the red cells of patient $H$. S., while the interrupted lines depict the average values for normal red cells in this laboratory. The solid circles indicate the values for unincubated blood, and the empty circles for incubated blood. 
TABLE III

Observations relating to red cell production and destruction in 20 patients with cirrhosis and anemia

\begin{tabular}{|c|c|c|c|c|c|c|c|c|c|}
\hline \multirow[b]{2}{*}{ Patient } & \multirow{2}{*}{$\begin{array}{c}\text { Hemo- } \\
\text { globin } \\
\text { (on ad- } \\
\text { milesion) } \\
\text { gm. \% }\end{array}$} & \multirow{2}{*}{$\begin{array}{c}\text { Red cell } \\
\text { half- } \\
\text { survival } \\
\text { time } \\
\text { doys }\end{array}$} & \multirow{2}{*}{$\begin{array}{c}\text { Estimated } \\
\text { rate of } \\
\text { hemoglobin } \\
\text { production } \\
\text { gm./dey } \\
\end{array}$} & \multicolumn{2}{|c|}{ Urobilinogen excretion } & \multirow{2}{*}{$\begin{array}{c}\text { Serum } \\
\text { iron } \\
\text { (mean. } \\
\text { 1 S.D.). } \\
\text { M..\% }\end{array}$} & \multirow{2}{*}{$\begin{array}{c}\text { Serum total } \\
\text { iron-binding } \\
\text { capacity } \\
\text { (mean } \pm \\
\text { 1S.D.) } \\
\text { M8. \% }\end{array}$} & \multicolumn{2}{|c|}{ Estimated iron content } \\
\hline & & & & Urine & me./day & & & Marrow & Liver \\
\hline $\begin{array}{l}\text { Normal } \\
\text { J.B. } \\
\text { J. L. } \\
\text { E. L. } \\
\text { B. L. } \\
\text { M.H. } \\
\text { J.R. } \\
\text { H.S. } \\
\text { J.G. } \\
\text { D.L. } \\
\text { M.Sc. } \\
\text { M.C. } \\
\text { F.T: } \\
\text { M. L. } \\
\text { A. J. } \\
\text { L.S: } \\
\text { M.D. } \\
\text { H.B. } \\
\text { J. Ba.* } \\
\text { A. K.* } \\
\text { M.S.* }\end{array}$ & $\begin{array}{c}15(12-18) \\
9.6 \\
10.5 \\
6.9 \\
9.9 \\
12.1 \\
13.6 \\
8.3 \\
10.5 \\
5.1 \\
9.3 \\
9.0 \\
9.8 \\
7.9 \\
6.7 \\
5.8 \\
7.1 \\
5.4 \\
2.9 \\
4.6 \\
5.7\end{array}$ & $\begin{array}{c}60(52-68) \\
17 \\
49 \\
11 \\
21 \\
30 \\
37 \\
27 \\
49 \\
5 \\
23 \\
- \\
75 \\
t \\
7 \ddagger \\
19 \\
11 \\
30 \\
22\end{array}$ & $\begin{array}{r}7.0 \\
11.9 \\
11.0 \\
8.8 \\
4.8 \\
8.9 \\
9.2 \\
8.7 \\
7.9 \\
22.5 \\
9.8 \\
- \\
21.1 \\
- \\
11.6 \\
15.9 \\
12.9 \\
10.0 \\
7.5\end{array}$ & $\begin{array}{c}1.0(0-4) \| \\
38 \\
7 \\
40 \\
21 \\
47 \\
36 \\
38 \\
25 \\
6 \\
3 \\
2 \\
63 \\
20 \\
6 \\
121 \\
82 \\
76 \\
9 \\
4 \\
-\end{array}$ & $\begin{array}{c}173(40-280) \| \\
308 \\
242 \\
83 \\
112 \\
948 \\
149 \\
263 \\
276 \\
276 \\
108 \\
139 \\
828 \\
6658 \\
180 \\
1568 \\
2288 \\
396 \\
439 \\
149 \\
122\end{array}$ & $\begin{array}{c}121.3 \pm 36.1 \\
79 \\
53 \\
73 \\
76 \\
125 \\
98 \\
105 \\
133 \\
41 \\
51 \\
49 \\
102 \\
65 \\
109 \\
120 \\
63 \\
107 \\
137 \\
100 \\
90\end{array}$ & $\begin{array}{c}303.1 \pm 64.9 \\
239 \\
183 \\
173 \\
132 \\
\overline{198} \\
212 \\
270 \\
142 \\
219 \\
221 \\
294 \\
\overline{251} \\
= \\
\overline{157} \\
267 \\
266 \\
218\end{array}$ & $\begin{array}{r}t \\
+ \\
+\end{array}$ & $\begin{array}{c}0-+ \\
+ \\
+ \\
++\end{array}$ \\
\hline Average & 8.0 & 22.7 & 11.4 & 33.9 & 223.4 & 88.8 & 215.1 & $2+$ & $2+$ \\
\hline
\end{tabular}

* Co-existing folic acid deficiency.

t Probable immune phenomenon.

$\ddagger$ Determined with $\mathrm{Cr}^{51}$-tagged autogenous red cells with correction for estimated red cell $\mathrm{Cr}^{51}$ elution (36) Biliuria present at time of determinations.

i| Reference 31.

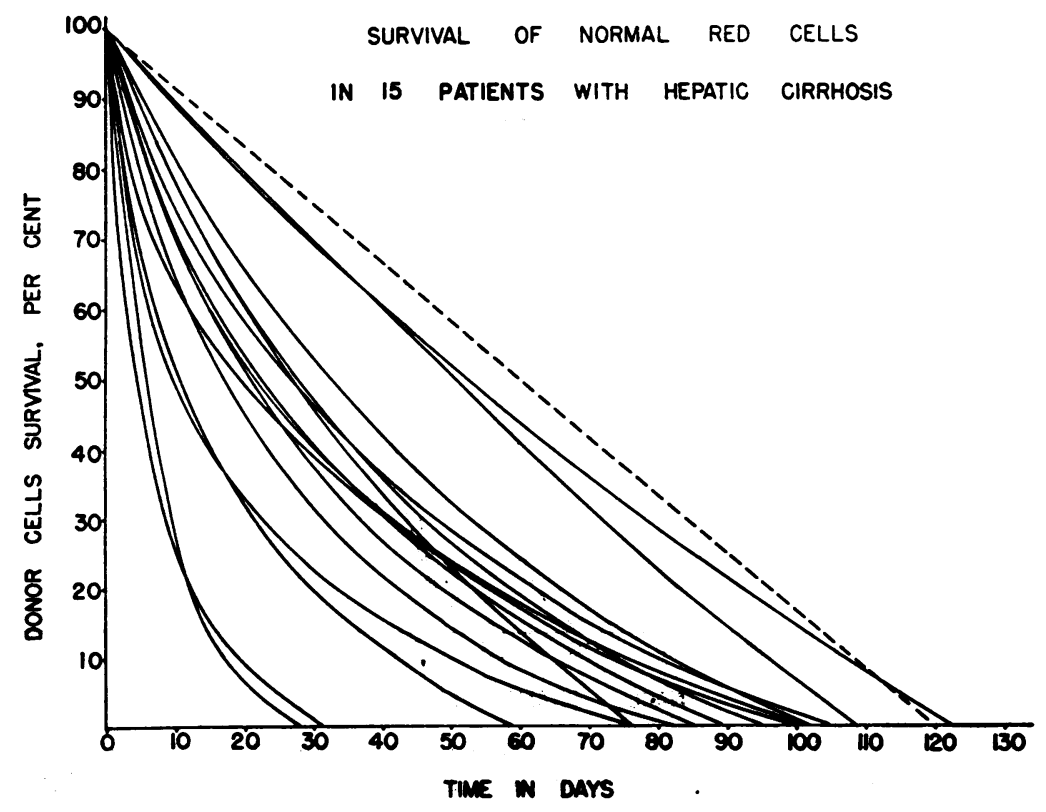

Fig. 3. The Survival, Detrrmuned by the Ashby Method, of Norical Red Cells Transfused Into 15 Patients with Cirrhosis and Various DeGREES OF ANEMIA

The interrupted straight line represents normal red cell survival. 
intersected the curves of the unincubated bloods. Incubation produced an abnormally great increase in red cell mechanical fragility in most of the patients. These changes, upon incubation, in the osmotic fragility curve and in the mechanical fragility values of the red cells of patient $H$. S. are characteristic of the group and are presented in Figure 2.

\section{Immunologic and chemical studies}

The search for abnormal immunologic mechanisms in these 20 patients was largely unrewarded. Elevated cold panagglutinins were present in patients M. L. and M. D., in titers of $1 / 16$ and $1 / 128$, respectively. The serum of $A$. J. transiently contained weak auto-agglutinins at $4^{\circ} \mathrm{C}$. and occasionally at $25^{\circ} \mathrm{C}$. In no other instances were abnormal agglutinins or hemolysins found. The red cells of none of the patients were agglutinable by antiglobulin serum. In six instances, sterile incubation of the patients' red cells and of normal red cells in the patients' sera at $37^{\circ} \mathrm{C}$. for as long as 96 hours resulted in no abnormal increase in the hemoglobin content of any of the supernatant sera. Trypsinized normal red cells were not agglutinated by the sera of the six patients tested.

The whole blood of the six patients so tested had normal concentrations of reduced and total glutathione. In all 12 patients tested, alkali-resistant hemoglobin concentrations were below 2 per cent of the total hemoglobin. The spectrophotometric pattern between wave lengths of 400 to $700 \mathrm{~m} \mu$. of the hemoglobin solutions of six patients was normal. Attempts to distinguish the hemoglobin of patients J. B. and M. D. from normal hemoglobin by means of paper electrophoresis ${ }^{4}$ were unsuccessful.

The serum iron levels were in the low normal to subnormal range for this laboratory, with a mean value of $88.8 \mu \mathrm{g}$. per $100 \mathrm{ml}$. of serum (Table III). The mean serum iron-binding capacity was significantly reduced in the 17 patients tested; being $215.1 \pm 52.1 \mu \mathrm{g}$. ( 1 standard deviation) per $100 \mathrm{ml}$. as compared to $303.1 \pm 64.9 \mu \mathrm{g}$. per 100 ml. of serum in 12 normal subjects. In patients M. L., L. S., and M. D., persistent jaundice prevented satisfactory determinations of iron-binding capacity because of colorimetric interference by

\footnotetext{
4 Kindly performed by Dr. Mortimer S. Greenberg.
}

the bilirubin. The mean iron saturation of the serum of the patients tested was 41.3 per cent compared to the normal mean of 40.1 per cent. Semi-quantitative estimations of the hemosiderin content of the marrow and the liver indicated normal or increased tissue deposits of iron in all 20 patients. An increase in tissue hemosiderin was consistently present in the four patients who later responded to folic acid. Hepatic hemosiderin deposits were largely present in the liver cells and the periportal areas; hemofuscin was not found.

The mean total urobilinogen excretion of these patients was $257.3 \mathrm{mg}$. per day (Table III) which, in the presence of the mean hemoglobin level of $8 \mathrm{gm}$. per cent, represents a distinct increase. There was a rough correlation between the degree of anemia and the quantity of urobilinogen excreted expressed as milligrams of urobilinogen per kilogram of body weight.

\section{Red cell survival}

The survival of normal red cells in the 15 cirrhotic patients in whom studies employing the Ashby technique were completed is represented in Figure 3. It can be seen that the rapidity of red cell destruction varied greatly in different patients, although the survival curves were consistent in shape. That the rate of the destructive process correlates with the degree of anemia is evident in Figure 4, in which the half-survival time of normal red cells transfused into 14 patients

TABLE IV

The relationship between hemoglobin levels and the rate of
hemoglobin production and destruction in three patients
with cirrhosis and anemia on whom two
survival studies were performed
(I and $I I)$

\begin{tabular}{lrrrrr}
\hline \hline & \multicolumn{2}{c}{ Hemoglobin } & & \\
\cline { 2 - 5 } & & $\begin{array}{c}\text { Prior } \\
\text { to } \\
\text { trans- } \\
\text { fusion } \\
\text { Patient }\end{array}$ & $\begin{array}{c}\text { Change } \\
\text { during } \\
\text { survival } \\
\text { period }\end{array}$ & $\begin{array}{c}\text { Red cell } \\
\text { half- } \\
\text { survival } \\
\text { time } \\
\text { days }\end{array}$ & $\begin{array}{c}\text { Estimated } \\
\text { rate of } \\
\text { hemoglobin } \\
\text { production } \\
\text { gm./day }\end{array}$ \\
\hline J. B. & I & 8.1 & +1.1 & 17 & 11.9 \\
& II & 9.5 & -0.5 & 23 & 10.6 \\
E. L. & I & 7.9 & +2.4 & 11 & 8.8 \\
II & 10.5 & +1.8 & 14 & 9.4 \\
D. L. & I & 8.5 & +2.0 & 5 & 22.5 \\
& II & 10.8 & +1.7 & 5 & 30.2 \\
\hline
\end{tabular}




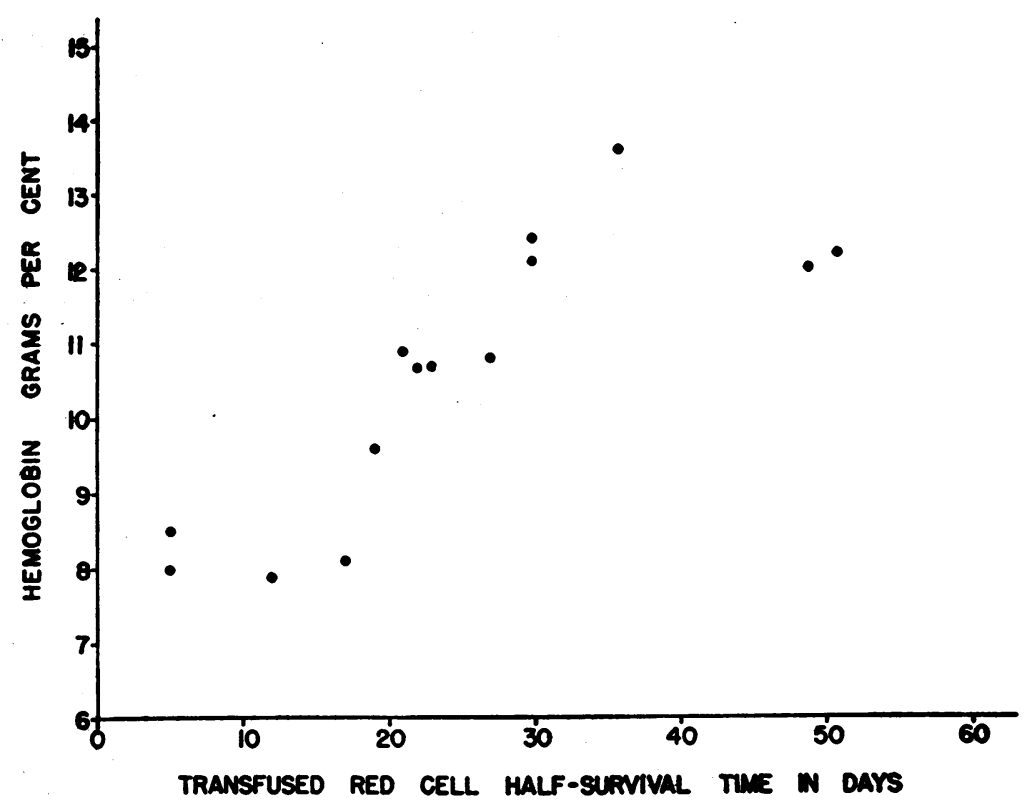

Fic. 4. The Correlation between the Patients' Hemoglobin Leveis and the Half-Survival Times of Transfused Normal Red Cemls

The ordinate represents the patients' hemoglobin levels at the time of transfusion. Red cell survival was determined by the Ashby method.

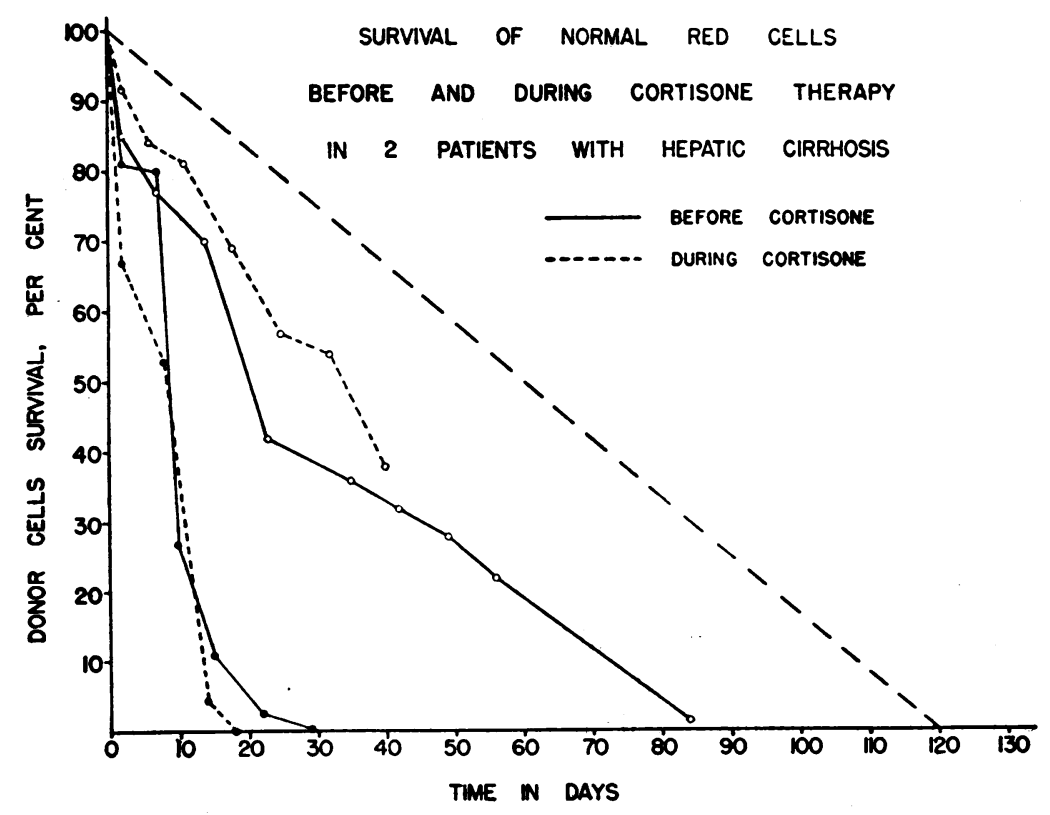

Fig. 5. The Failure of Cortisone Administration to Affect the Rate of Red Cell Destruction in Two Patients with Cirrhosis and Anemia

The solid circles represent patient D. L. and the empty circles patient J. B. Red cell survival before cortisone administration is depicted by solid lines, and during cortisone administration by interrupted fine lines. The interrupted straight heavy line indicates normal red cell survival. 
with cirrhosis is plotted against the recipients' hemoglobin levels at the time of transfusion. ${ }^{5}$ In three patients survival studies were performed at least twice. As indicated in Table IV, the hemoglobin levels increased with or without improvement in red cell survival. In two patients, J. B. and D. L., survival studies were performed for the second time and the third time, respectively, during the period when both were receiving $200 \mathrm{mg}$. of cortisone acetate orally daily (Figure 5). There was no evident effect upon red cell survival.

\section{Nutritional factors}

Ascorbic acid was not present in the venous blood buffy coats of 11 of 16 patients tested. Only one of these patients, J. Ba., had clinical scurvy. Total serum Vitamin $B_{12}$ levels in the 20 patients ranged from 193 to $1932 \mu \mu \mathrm{g}$. per milliliter with a mean value of $601 \mu \mu$ g., compared to $532 \pm$ $161 \mu \mu \mathrm{g}$. (1 standard deviation) in 20 normal people. Patients H. B., J. Ba., A. K., and M. S., who developed significant and sustained hematologic responses to folic acid, had buffy coat ascorbic acid and serum Vitamin $B_{12}$ levels comparable to the group as a whole. No evidence of responsiveness to folic acid or to citrovorum factor, or of abnormalities of folic acid metabolism, was discovered in any of the other 16 patients. Three patients (J. B., E. L., and J. M.) who received 0.6 to $1 \mathrm{gm}$. of ferrous sulfate orally daily and three patients (J. B., D. L., and A. J.) who received $200 \mathrm{mg}$. of cortisone acetate orally daily showed no response of reticulocyte or hemoglobin levels to either medication.

\section{DISCUSSION}

These observations on 20 patients with cirrhosis suggest that the anemia associated with liver disease, when not a result of superimposed folic acid deficiency or of blood loss, may be moderately severe and is generally self-limited. None of the 16 patients with uncomplicated anemia of liver disease had a hemoglobin level below 5 gm. per

5 Patient J. Ba. was transfused during the course of a response to folic acid and was thus excluded from Figure 4. The other patients deficient in folic acid had stabilized their hemoglobin levels prior to the survival studies. cent, and only five had levels below $7.5 \mathrm{gm}$. per cent. Similarly, macrocytosis was not extreme in any of these 16 patients and correlated in degree only roughly with the severity of the anemia. Indeed, macrocytosis frequently has been observed in this laboratory in patients with cirrhosis uncomplicated by anemia. However, the appearance in a patient with chronic liver disease of a hemoglobin of less than $5 \mathrm{gm}$. per cent or of a mean corpuscular volume of more than $130 \mu^{8}$ should alert one to the possibility of superimposed folic acid deficiency. The presence of abnormally large granulocytes in the peripheral blood showing peculiarities of nuclear chromatin, particularly in the presence of leukopenia, or in the presence of low reticulocyte levels, is also suggestive of folic acid deficiency. Coincidental Vitamin $B_{12}$ deficiency is, of course, possible although it was not observed in this series. In those patients with no nutritional component to the anemia, the peripheral smear showed a characteristic association of macrocytosis with increased polychromatophils, target cells and, frequently, stippled cells.

In the bone marrows of several of the 16 patients with uncomplicated anemia of liver disease, particularly of those with the lowest hemoglobin levels (Table I), there were small numbers of red cell precursors of various stages of maturity which were large and possessed abnormalities of nuclear chromatin and mitosis characteristic of so-called megaloblasts. The degree of morphologic change and the frequency of such abnormal red cell precursors in these patients were not as marked as in the four patients demonstrated to have folic acid deficiency. Admittedly, the lesser severity of the anemia in the larger group may make such a morphologic distinction less meaningful. It is of interest, therefore, that in all the patients deficient in folic acid striking abnormalities of the granulocyte series characteristic of Vitamin $B_{12}$ deficiency or of folic acid deficiency were evident. These abnormalities were not present in the other patients.

There was no evident correlation between the duration of the illness and the degree of anemia or of liver damage, or between the severity of the anemia and the clinical outcome. The tendency of the anemia to remit spontaneously during or following the appearance of signs of improved liver 
function in association with a persistent reticulocytosis was characteristic, although an elevated reticulocyte level was by no means a harbinger of clinical recovery.

The development of a reticulocyte peak on an average seven days after admission in five patients who on admission had ceased their alcoholic intake and who were given diets low or lacking in known hemopoietic factors (Figure 1) suggests that cessation of alcoholic intake is followed by increased erythropoietic activity. This interpretation is supported by the presence of initially elevated and thereafter declining daily reticulocyte values in three patients who had ceased drinking one or two weeks before admission. Conceivably, the appearance of a reticulocyte rise on cessation of alcoholic intake represents a release of the marrow either from a direct toxic suppression or from an indirect toxic action as a consequence of injury to the liver. The fact that in patients M. L. and M. D. reticulocyte levels remained elevated and hemoglobin production remained moderately high concurrently with evidence of increased liver damage eventuating in hepatic coma, indicates that actively progressing hepatic failure does not necessarily suppress hemoglobin production; rather it favors the possibility of a direct suppression of the marrow by alcohol. It is interesting to note that in one of two series of 11 rats rendered anemic and cirrhotic by carbon tetrachloride inhalation (8), a reticulocyte rise occurred which reached a maximum about five days after cessation of the toxic exposure.

The evidence presented in Figures 3 and 4 indicates that an increased rate of red cell destruction is present in patients with cirrhosis who have subnormal hemoglobin levels, and that the rate of red cell destruction correlates with the degree of anemia. This hemolytic process was associated with the triad of findings characteristic of hemolytic anemias: Persistently elevated reticulocyte levels; an increased concentration of red cell precursors in the marrow; and heightened urobilinogen excretion. A hemolytic process such as this, which affects the survival of normal red cells as determined by the Ashby method, is extracorpuscular by definition. This does not exclude an additional primary corpuscular defect which would not be distinguishable from an acquired and irreversible corpuscular defect even if transfusion studies of patients' cells in normal subjects were to show shortened survival. The consistently exponential character of the survival curves of normal red cells in these patients is characteristic of most extracorpuscular hemolytic processes and has classically been attributed to indiscriminate or random red cell destruction. The cumulative effect of a diffuse toxic or unfavorable environment would be characterized by survival curves of normal transfused red cells of a sigmoidal character indicating a period of maximal rate of destruction. One can reason, therefore, that survival curves such as these that approach the exponential form are the result of a continuous fractional removal of red cells by a process which is intensive and localized rather than by a process which is diffuse. Such a mechanism might be limited spatially as by organ sequestration or stoichiometrically as by the continuous production of a rapidly acting hemolysin in amounts sufficient only to destroy a limited number of cells. Conceivably, of course, a diffuse circulating factor such as an agglutinin might well predispose to ultimate destruction on a random but local basis. In the absence of any demonstrable circulating agglutinin or hemolysin, the presence of survival curves approaching an exponential character in the anemia of cirrhosis suggests the possibility of a local site of random destruction; pathologically the liver and the spleen are the organs most suspect in this disease. Current studies in this laboratory indicate that following transfusion with $\mathrm{Cr}^{51}$-tagged autogenous red cells into patients with cirrhosis, there is a heavy concentration of radioactivity in the spleen, and abnormally little activity in the liver. This is in contrast to the distribution of $\mathrm{Cr}^{51}$ following the injection of $\mathrm{Cr}^{51}$ tagged hemoglobin solutions, and suggests that the spleen is the major site of red cell destruction in patients with cirrhosis and anemia. The correlation present between the rate of red cell detruction and a maintained degree of anemia implies that the production of hemoglobin by the marrow is proportional to the degree of anoxia and approaches a maximum as anoxic stimulation increases, rather than reaching a maximum beyond which anemia commences, as has been implied by Crosby and Akeroyd (43).

In no instance in this series did the anemia progress while the patient was in the hospital. 
From red cell survival studies, it was calculated that the maximum daily rate of hemoglobin production in these 20 patients on entry was about three times the normal rate. ${ }^{\circ}$ Since the hemoglobin levels improved in patient D. L. without a reduction in the rate of hemolysis, an improved rate of production may largely account for this spontaneous recovery. This may, as noted, be due in part to an improved marrow response on withdrawal of alcohol. Furthermore, it seems likely that patients on an inadequate or marginal diet may develop nutritional deficiencies more rapidly in the presence of accelerated red cell turnover, and that such deficiencies, as in the four patients described, may become the limiting factor in hematopoiesis.

The failure of cortisone to improve the red cell survival in patients J. B. and D. L., and in A. J., who developed an unusual immune process resulting in strikingly short survival of the cells of certain donors without in vitro evidence of incompatibility during the course of her first and subsequent transfusions, is of interest since recent evidence has suggested a non-specific inhibitory influence of adrenocortical hormones upon red cell removal from tissues $(44,45)$. Since all three patients manifested physical signs of excessive adrenocortical effect while on therapy, and since equal and smaller doses of cortisone have been reported to retard the dispersion of intradermally injected red cells (46), it is unlikely that either inefficient conversion of the cortisone to a physiologic substance or inadequate dosage explains the absence of effect of cortisone upon red cell survival in these patients. In contrast to a report (47) suggesting a stimulating effect of ACTH on red cell production in patients with cirrhosis, there was no indication that cortisone produced an erythropoietic response in the patients in this series.

The "osmotic fragility" of a red cell is in essence a measure of the difference between its (isotonic) volume in the blood and its volume as a sphere of equal surface at the moment of rupture in hypotonic saline (48). The amounts of he-

\footnotetext{
- Hemoglobin production was calculated by means of a simplified planimetric method which is applicable to nonhomeostatic states, and in which hemoglobin turnover is derived from red cell survival and blood volume data.
}

moglobin released from equal aliquots of red cells in a graded series of hypotonic solutions of sodium chloride may be charted as shown in Figure 2 , which displays results on patient $H$. S. typical of the group. For normal red cells a sigmoid curve is produced. The osmotic fragility curve of the red cells of these patients was essentially similar or else was shifted in its upper portion slightly to the right of the osmotic fragility curve of normal red cells. After incubation, of the patient's red cells, however, this shift to the right became more pronounced so that the upper part of the osmotic fragility curve of the incubated red cells actually lay to the right of the curve of the unincubated red cells. This phenomenon occurs in several types of anemia. It indicates that a portion of the patient's more resistant red cells have lost osmotically active material during incubation, presumably as a result of a breakdown of the ability of the red cell membrane to maintain a normal gradient between intracellular and extracellular substances. Further evidence of such damage to the cell membrane was indicated by an abnormally great increase, upon incubation, of the mechanical fragility of the patients' red cells (23).

The possibility that the abnormalities in osmotic fragility appearing on incubation were acquired defects was explored by transfusing $\mathrm{Cr}^{51}$-tagged normal red cells into patient M. D., and thereafter repeatedly determining their osmotic fragility after 24 hours' incubation. Counts of the $\mathrm{Cr}^{51}$ activity of the supernatant solutions of each osmotic fragility test indicated that the transfused normal red cells became progressively less osmotically resistant as these red cells were cleared from the patient's circulation. This shift was symmetrical, with no evidence of cell membrane damage as defined above. This single series of observations suggests that the hemolytic process in cirrhosis may be associated with spherocyte formation.

In contrast to patients with obstructive jaundice and infectious hepatitis $(18,19)$, no evidence of diffuse red cell "flattening" was found in patients with cirrhosis as determined either by direct measurement of red cell volume and diameter and calculation of thickness, or by increase in osmotic resistance of the entire cell population of samples of unincubated blood. However, as noted, small numbers of target cells were commonly present 
and a small portion (about 15 per cent) of the unincubated red cells showed increased resistance to osmotic lysis. Thus the factor in patients with hepatitis and obstructive jaundice that is capable of "flattening" normal red cells in vivo (17) is presumably not operative in producing the anemia of liver disease. The lack of correlation between the degree of anemia and the fragility changes described suggests that these characteristics are not basic to the excessive red cell destruction.

Efforts to demonstrate spectroscopic and electrophoretic abnormalities of the hemoglobin of these patients were unsuccessful. It would be of interest, therefore, to explore further the observation by Keys and Snell (49) that abnormal oxygen dissociation curves occurred in several patients with chronic liver disease.

The finding in these patients of reduced serum iron-binding capacities, in association with generally increased hemosiderin deposits in the marrow and liver resembles, although to a less marked degree, previous observations made upon patients with the anemia of infection $(50,51)$. Although the amount of hemosiderin in the liver parenchyma of several patients was considerable, the presence of normal to low serum iron concentrations and iron-binding capacities and the absence of hemofuscin in the liver differentiate this situation clearly from early hemochromatosis.

\section{SUMMARY}

Studies of 20 cirrhotic patients with anemia not caused by blood loss indicate that an extracorpuscular hemolytic process was present which was proportional in severity to the degree of anemia. The mechanism of this hemolysis appears to have consisted in local destruction of red cells, probably through their sequestration in the spleen. Hemoglobin production, despite persistence of the anemia, did not generally exceed two or three times the normal rate, which suggests a diminished sensitivity to anoxia. This insufficient capacity to produce hemoglobin may have been impaired further by the ingestion of alcohol. Improvement in hemoglobin levels, at least initially, may be largely a result of increased production rather than of a decrease in the rate of destruction. In four patients, folic acid deficiency was the factor limiting hematopoiesis.

\section{REFERENCES}

1. Wintrobe, M. M., and Shumacker, H. S., Jr., The occurrence of macrocytic anemia in association with disorder of the liver, together with a consideration of the relation of this anemia to pernicious anemia. Bull. Johns Hopkins Hosp., 1933, $52,387$.

2. Goldhamer, S. M., Isaacs, R., and Sturgis, C. C., The rôle of the liver in hematopoiesis. Am. J. M. Sc., 1934, n.s., 188, 193.

3. Wintrobe, M. M., Relation of disease of the liver to anemia. Type of anemia, response to treatment, and relation of type of anemia to histopathologic changes in liver, spleen and bone marrow. Arch. Int. Med., 1936, 57, 289.

4. Limarzi, L. R., Jones, R. M., Paul, J. T., and Poncher, H. G., Sternal marrow in Banti's syndrome and other splenomegalic states. The effect of splenectomy. Am. J. Clin. Path., 1943, 13, 231.

5. Berman, L., Axelrod, A. R., Horan, T. N., Jacobson, S. D., Sharp, E. A., and VonderHeide, E. C., The blood and bone marrow in patients with cirrhosis of the liver. Blood, 1949, 4, 511.

6. Jarrold, T., and Vilter, R. W., Hematologic observations in patients with chronic hepatic insufficiency. Sternal bone marrow morphology and bone marrow plasmacytosis. J. Clin. Invest., 1949, 28, 286.

7. Schiff, L., Rich, M. L., and Simon, S. D., "Haematopoetic principle" in the diseased human liver. Am. J. M. Sc., 1938, n.s., 196, 313.

8. Heinle, R. W., Castle, W. B., and Rose, F. A., Interpretation of the macrocytic anemia in experimental liver injury. Folia haemat., 1940, 64, 174.

9. Bateman, J. C., Shorr, H. M., and Elgvin, T., Hypervolemic anemia in cirrhosis. J. Clin. Invest., 1949, 28, 539.

10. Fellinger, K., and Klima, R., Lebercirrhose und Anämien. Ztschr. f. klin. Med., 1934, 126, 547.

11. Rosenberg, D. H., Macrocytic anemia in liver disease, particularly cirrhosis. Observations on the incidence, course and reticulocytosis with a correlated study of the gastric acidity. Am. J. M. Sc., 1936, n.s., 192, 86.

12. Higgins, G. M., and Stasney, J., The peripheral blood in experimental cirrhosis of the liver. Folia haemat., 1935, 54, 129.

13. Stasney, J., and Higgins, G. M., The blood-forming organs in experimental cirrhosis of the liver. Folia haemat., 1936, 55, 93.

14. Watson, C. J., Studies of urobilinogen. III. The per diem excretion of urobilinogen in common forms of jaundice and disease of the liver. Arch. Int. Med., 1937, 59, 206.

15. Watson, C. J., Hemolytic jaundice and macrocytic hemolytic anemia: certain observations in a series of 35 cases. Ann. Int. Med., 1939, 12, 1782. 
16. Hyman, G. A., and Southworth, H., Hemolytic anemia associated with liver disease. Am. J. M. Sc., 1951, n.s., 221, 448.

17. Harris, J. W., and Schilling, R. F., Increased resistance to osmotic lysis as an acquired change in the erythrocytes of patients with hepatogenous jaundice or biliary obstruction. J. Clin. Invest., $1950,29,820$.

18. Barrett, A. M., A special form of erythrocyte possessing increased resistance to hypotonic saline. J. Path. \& Bact., 1938, 46, 603.

19. Bohr, D. F., Erythrocyte fragility in acute infectious hepatitis. J. Lab. \& Clin. Med., 1946, 31, 1179.

20. Ham, T. H., A syllabus of laboratory examinations in clinical diagnosis. Critical evaluation of laboratory procedures in the study of the patient. Cambridge, Harvard University Press, 1950.

21. Shen, S. C., and Ham, T. H., Studies on the detruction of red blood cells. III. Mechanism and complications of hemoglobinuria in patients with thermal burns: spherocytosis and increased osmotic fragility of red blood cells. New England J. Med. 1943, 229, 701.

22. Ham, T. H., Emerson, C. P., Shen, S. C., Fleming, E. M., and Castle, W. B., To be published.

23. Shen, S. C., Castle, W. B., and Fleming, E. M., Experimental and clinical observations on the increased mechanical fragility of erythrocytes. Science, 1944, n.s., 100, 387.

24. Gardner, F. H., The transfer to normal red cells of an agglutinin demonstrable in the acidified sera of patients with acquired hemolytic jaundice. J. Clin. Invest., 1949, 28, 783.

25. Coombs, R. R. A., Mourant, A. E., and Race, R. R., A new test for the detection of weak and "incomplete" Rh agglutinins. Brit. J. Exper. Path., 1945, 26, 255.

26. Rosenthal, M. C., Dameshek, W., and Burkhardt, R., Trypsin-modified erythrocytes. Their use as test cells in acquired hemolytic anemia. Am. J. Clin. Path., 1951, 21, 635.

27. Woodward, G. E., and Fry, E. G., The determination of blood glutathione. J. Biol. Chem., 1932, 97, 465.

28. Singer, K., Chernoff, A. I., and Singer, L., Studies on abnormal hemoglobins. I. Their demonstration in sickle cell anemia and other hematologic disorders by means of alkali denaturation. Blood, 1951, 6, 413.

29. Kitzes, G., Elvehjem, C. A., and Schuette, H. A., The determination of blood plasma iron. J. Biol. Chem., 1944, 155, 653.

30. Rath, C. E., and Finch, C. A., Chemical, clinical, and immunological studies on the products of human plasma fractionation. XXXVIII. Serum iron transport. Measurement of iron-binding capacity of serum in man. J. Clin. Invest., 1949, 28, 79.

31. Schwartz, S., Sborov, V., and Watson, C. J., Studies of urobilinogen. IV. The quantitative determina- tion of urobilinogen by means of the Evelyn photoelectric colorimeter. Am. J. Clin. Path., 1944, 14, 598.

32. Rutstein, D. D., Ingenito, E. F., and Reynolds, W. E., The determination of albumin in human blood plasma and serum. A method based on the interaction of albumin with an anionic dye-2-(4'hydroxy-benzeneazo) benzoic acid. J. Clin. Invest., 1954, 33, 211.

33. Keys, A., A rapid micro-Kjeldahl method. J. Biol. Chem., 1940, 132, 181.

34. Ashby, W., The determination of the length of life of transfused blood corpuscles in man. J. Exper. Med., 1919, 29, 267.

35. Gray, S. J., and Sterling, K., The tagging of red cells and plasma proteins with radioactive chromium. J. Clin. Invest., 1950, 29, 1604.

36. Ebaugh, F. G., Jr., Emerson, C. P., and Ross, J. F., The use of radioactive chromium ${ }^{\text {an }}$ as an erythrocyte tagging agent for the determination of red cell survival in vivo. J. Clin. Invest., 1953, 32, 1260.

37. Read, R. C., Quoted in Abbott Radioactive Pharmaceuticals, Jan., 1954.

38. Butler, A. M., and Cushman, M., Distribution of ascorbic acid in the blood and its nutritional significance. J. Clin. Invest., 1940, 19, 459.

39. Ross, G. I. M., Vitamin $B_{12}$ assay in body fluids using Euglena gracilis. J. Clin. Path., 1952, 5, 250.

40. Teply, L. J., and Elvehjem, C. A., The titrimetric determination of "lactobacillus casei factor" and "folic acid." J. Biol. Chem., 1945, 157, 303.

41. Sauberlich, H. E., and Baumann, C. A., A factor required for the growth of Leuconostoc citrovorum. J. Biol. Chem., 1948, 176, 165.

42. Jand1, J. H., and Gabuzda, G. J., Jr., Potentiation of pteroylglutamic acid by ascorbic acid in anemia of scurvy. Proc. Soc. Exper. Biol. \& Med., 1953, 84, 452.

43. Crosby, W. H., and Akeroyd, J. H., The limit of hemoglobin synthesis in hereditary hemolytic anemia. Am. J. Med., 1952, 13, 273.

44. Kass, E. H., Kendrick, M. I., and Finland, M., The effect of certain corticosteroids and of growth hormone on nucleoproteins of lymph nodes. Ann. New York Acad. Sc., 1953, 56, 737.

45. Benedict, W. H., and Hollenhorst, R. W., The influence of cortisone on the rate of blood absorption from the eye. Am. J. Ophth., 1953, 36, 247.

46. Lovell, R. R. H., Scott, G. B. D., Hudson, B., and Osborne, J. A., The effects of cortisone and adrenocorticotrophic hormone on dispersion of bruises in the skin. Brit. J. Exper. Path., 1953, $34,535$.

47. Brown, H., Jager, B. V., and Tyler, F. H., ACTH in cirrhosis of the liver. Am. J. Med., 1951, 10, 770.

48. Castle, W. B., and Daland, G. A., Susceptibility of mammalian erythrocytes to hemolysis with hypo- 
tonic solutions. A function of differences between discoidal volume and volume of a sphere of equal surface. Arch. Int. Med., 1937, 60, 949.

49. Keys, A., and Snell, A. M., Respiratory properties of the arterial blood in normal man and in patients with disease of the liver: Position of the oxygen dissociation curve. J. Clin. Invest., 1938, 17, 59.
50. Cartwright, G. E., and Wintrobe, M. M., Chemical, clinical and immunological studies on the products of human plasma fractionation. XXXIX. The anemia of infection. Studies on the iron-binding capacity of serum. J. Clin. Invest., 1949, 28, 86.

51. Wintrobe, M. M., Clinical Hematology, 3rd. ed., Philadelphia, Lea \& Febiger, 1951, pp. 546-547.

\section{ERRATUM}

In the article "Metabolic Effects of Marked Sodium Restriction in Hypertensive Patients: Changes in Total Exchangeable Sodium and Potassium" by L. K. Dahl, B. G. Stall, III, and G. C. Cotzias, J. Clin. Invest., 1954, 33, 1397, under 'Statistical analyses of significance' on page 1399, column 2, the formula $\sigma^{2}=\sqrt{\sigma_{1}{ }^{2}+\sigma_{2}{ }^{2}} \cdots$ should read $\sigma=\sqrt{\sigma_{1}{ }^{2}+\sigma_{2}{ }^{2}} \cdots$."

\section{ERRATUM}

The following changes should be made in the paper "Quantitative Aspects of Iodine Metabolism" by S. A. Berson and R. S. Yalow, J. Clin. Invest., 1954, 33, 1533. With exception of equations 7 and 8 which are correct as they stand, $\lambda_{1}$ and $\lambda_{2}$ have been inadvertently transposed throughout the remainder of the appendix beginning with equation 5, page 1552. Thus $\lambda_{1}$ should read $\lambda_{2}$ and $\lambda_{2}$ should read $\lambda_{1}$. 